\title{
ID1 Gene
}

National Cancer Institute

\section{Source}

National Cancer Institute. ID1 Gene. NCI Thesaurus. Code C99648.

This gene plays a role in transcriptional repression. 